\title{
Selected individual determinants of cereal, fruit and vegetable consumption among menopausal women in view of potential health risks
}

\author{
Niektóre różnice indywidualne jako determinanty konsumpcii produktów zbożowych oraz warzyw i owoców \\ w grupie kobiet w wieku okołomenopauzalnym w świetle zagrożeń stanu zdrowia
}

\author{
Maria Gacek \\ Department of Sports Medicine and Human Nutrition, University School of Physical Education in Krakow; \\ head of Department: dr hab. Zbigniew Szyguła, prof. nadzw.
}

Przegląd Menopauzalny 2013; 5: 385-391

\section{Summary}

The aim of this study was to analyze some personal determinants of cereal, fruit and vegetable consumption in a group of menopausal women. We analyzed selected individual characteristics, such as the level of general self-efficacy, optimism, and satisfaction with life. The study, using a questionnaire assessing the frequency of food product consumption and psychological scales (GSES, LOT-R, SWLS), included 320 women aged between 45 and 55 years.

Statistical analysis of the Spearman's rank coefficients of correlation revealed that increased BMI was associated with a significantly higher frequency of white bread consumption $(p<0.05)$, and decreased consumption of brown rice, whole grains $(p<0.01)$, wholegrain noodles, oat meal $(p<0.05)$, raw and green vegetables $(p<0.01)$, and fruits, including citruses $(p<0.01)$. The level of self-efficacy correlated positively with the consumption frequency of white rice $(p<0.05)$, noodles, raw, cooked, and green vegetables $(p<0.01)$, and fruits, including citruses $(p<0.01)$. The level of optimism was positively correlated with the frequency of brown rice, noodle, whole grain and oat meal consumption $(p<0.01)$. Higher levels of satisfaction with life were associated with more frequent consumption of brown rice, noodles, whole grains, oat meal $(p<0.01)$, and cooked vegetables $(p<0.05)$, as well as with a lower frequency of white bread consumption $(p<0.05)$. The tendencies documented in the correlation analysis were further confirmed by intergroup comparisons with the KruskalWallis and Dunn tests $(p<0.05)$.

Our study revealed that the frequency of selected cereal, fruit and vegetable consumption varies depending on individual characteristics, with a tendency to more rational nutritional choices among women with higher levels of self-efficacy, optimism and satisfaction with life.

Key words: women, menopause, dietary pattern, cereal products, vegetables, fruits, psychological traits.

\section{Streszczenie}

Celem badań była analiza niektórych osobniczych uwarunkowań konsumpcji produktów zbożowych oraz warzyw i owoców w grupie kobiet w wieku okołomenopauzalnym. Analizie poddano wybrane różnice indywidualne, w tym poziom uogólnionej skuteczności, optymizmu i satysfakcji życiowej. Badaniami, z wykorzystaniem kwestionariusza częstości spożycia produktów oraz testów psychologicznych (GSES, LOT-R, SWLS), objęto 320 kobiet w wieku 45-55 lat.

Analiza statystyczna korelacji rang Spearmana wykazała, że wraz ze wzrostem wartości wskaźnika masy ciała (body mass index - BMI) istotnie zwiększała się częstość spożycia pieczywa jasnego $(p<0,05)$, a zmniejszato spożycie ryżu razowego, kasz gruboziarnistych $(p<0,01)$, makaronu razowego, płatków owsianych $(p<0,05)$, warzyw surowych i zielonych $(p<0,01)$ oraz owoców, w tym cytrusowych $(p<0,01)$. Poziom skuteczności wykazywał dodatnią korelację z częstością spożycia ryżu jasnego $(p<0,05)$, makaronów, warzyw surowych, gotowanych i zielonych $(p<0,01)$ oraz owoców, w tym cytrusowych $(p<0,01)$. Poziom optymizmu był dodatnio skorelowany z częstością spożywania ryżu razowego, makaronów, kasz gruboziarnistych i płatków owsianych $(p<0,01)$. Wraz ze wzrostem poziomu satysfakcji z życia zwiększała się częstość spożycia ryżu razowego, makaronów, kasz gruboziarnistych i płatków owsianych $(p<0,01)$ oraz warzyw gotowanych $(p<0,5)$, a zmniejszało się spożycie 
pieczywa jasnego $(p<0,05)$. Tendencje stwierdzone $w$ analizie korelacji potwierdzono w porównaniach międzygrupowych testami Kruskala-Wallisa i Dunna $(p<0,05)$.

Wykazano zróżnicowanie częstości konsumpcji niektórych produktów zbożowych oraz warzyw i owoców w zależności od cech osobniczych, z tendencją do korzystniejszych wyborów u kobiet o wyższym poczuciu własnej skuteczności, optymizmu i satysfakcji życiowej.

Słowa kluczowe: kobiety, menopauza, sposób żywienia, produkty zbożowe, warzywa, owoce, cechy psychologiczne.

\section{Introduction}

Both Polish and Western dietary recommendations assume daily consumption of several servings of cereals, fruits and vegetables [1]. Wholegrain cereals, fruits and vegetables are characterized by high nutritional density, which is especially determined by their contents of dietary fiber, mineral salts, vitamin B complex, and antioxidants [2]. High nutritional density and content of bioactive compounds make these products important in the nutritional prevention of some non-communicable chronic disorders, especially obesity, type 2 diabetes mellitus, cardiovascular conditions, and some neoplasms [1, 3, 4]. In cancer chemoprevention especially active are folate [5], carotenoids [6] and included in cruciferous vegetables glucosinolates [7]. Increased risk of diet- and hormone-dependent chronic conditions in postmenopausal women [8, 9] stimulated research on the consumption of cereals, fruits and vegetables, as products important in their prevention [1].

Active involvement in self-improvement of one's health, associated with health-oriented lifestyle, including rational nutritional behaviors, is determined by an array of socioeconomic, cultural, and personality-related factors [10]. The levels of self-efficacy, optimism, and satisfaction with life occupy an important place among psychological determinants of health-oriented culture [11]. Self-efficacy, defined as a self-assessed ability to control events that can affect one's functioning, enables one to predict intentions and activities in various areas, including health-oriented behaviors [11]. Optimism, being a dispositional trait characterizing the expectation of positive outcome, represents an important personal resource affecting psychophysical status of an individual. Also the level of satisfaction with life is an important subjective indicator of health [11]. Consequently, a research was undertaken to verify the predictive role of some individual determinants of nutritional choices of menopausal women as they can be potentially exposed to various health risks.

The aim of this study was to analyze some personal determinants of nutrition with regards to the consumption of selected cereals, fruits and vegetables in a group of menopausal women. We analyzed selected psychological parameters, such as the level of general self-efficacy, optimism, and satisfaction with life, due to their prognostic value as determinants of health-oriented behaviors, including nutritional choices.

\section{Material and methods}

The study was conducted between 2010 and 2012 in a group of 320 women aged between 45 and 55 years $(X=51.23 \pm 2.45$ years). The participants were professionally active employees of various offices in Małopolska region. They all performed intellectual work, and had secondary (70\%) or higher education (30\%); most of them were married (80\%). Due to the principal objective of the study, a group homogenous in terms of sociodemographic characteristics was selected.

The frequency of consumption of cereals, fruits and vegetables was analyzed using a 7-item scale containing the following categories: several times a day (corresponding to 7 points), once a day (6 pts), several times a week (5 pts), once a week (4 pts), several times per month (3 pts), once a month (2 pts), and rarer/never (1 pt). Thirteen food products from the analyzed group, being determinants of nutrition and characterized by various nutritional value, were considered. Additionally, these products were identified as preferred by women on the basis of preliminary study. The frequency of consumption of examined products was examined with regards to the year preceding the study. Body mass index (BMI) was calculated on the basis of somatic measurements of body weight and body height. The levels of individual traits were determined with the validated tests: i) General Self-Efficacy Scale (GSES) by R. Schwarzer, M. Jerusalem and Z. Juczyński, ii) Life Orientation Test (LOT-R) by M. F. Scheier, Ch.S. Carver and M.W. Bridges, adapted by R. Poprawa and Z. Juczyński, and iii) Satisfaction with Life Scale (SWLS) by Ed Diener, R.A. Emmons, R.J. Larson and S. Griffin, adapted by Z. Juczyński. GSES was used to determine the level of general selfefficacy, while the optimistic disposition and overall satisfaction with life were measured with LOT-R and SWLS, respectively. The examined women were classified into the groups with low, moderate and high levels of self-efficacy, optimism, and satisfaction with life on the basis of relevant provisional Polish sten (standard ten) norms for adults [11].

Statistical analysis was conducted with PQStat ver. 1.4.2.324 software. The relationship between BMI, the levels of self-efficacy, optimism and satisfaction with life (GSES, LOT-R and SWLS scales) and the frequency of consumption of cereals, fruits and vegetables was estimated on the basis of Spearman's coefficients of rank correlation. The mean frequencies of consump- 
tion of the analyzed products associated with various levels of studied individual traits were compared with the Kruskal-Wallis test and with the Dunn test for multiple comparisons. Test probability was considered significant at $p<0.05$ and highly significant at $p<0.01$.

\section{Results}

White bread, consumed several times per week on average (5.05), was the cereal product which was chosen most often, contrary to wholegrain bread which was considered less frequently (4.53). Non-wholegrain noodles (3.43) and white rice (3.24) were consumed more frequently than several times per month. Whole grains (2.55) and oat meal (2.45) were considered less often than several times per month, and the consumption of wholegrain noodles (2.24) and brown rice (2.13) was the lowest of all cereal products. Vegetables, most commonly cooked, were considered with an average frequency of several times per week (5.04). The frequency of fruit consumption amounted to nearly once a day (5.79), and that of citrus fruits approximated to several times per week (4.91) (Table I).

Mean BMI of examined women amounted to $24.30 \pm 3.34 \mathrm{~kg} / \mathrm{m}^{2}$. Examination of medical history revealed that $48.8 \%$ of the participants had no chronic conditions; $25.0 \%$ of them suffered from arterial hypertension, $17.1 \%$ from hyperlipidemia, and $9.1 \%$ from rheumatic disorders. Mean level of self-efficacy (GSES score) amounted to $26.96 \pm 2.52$, and the levels of optimism (LOT-R) and satisfaction with life (SWLS) were $14.48 \pm 1.98$ and $20.05 \pm 2.32$, respectively. The median values of the abovementioned scales equaled 27,15 , and 20 points, respectively. The standardized values of the psychological tests ranged between 5.46 and 5.39, suggesting that the menopausal women represented moderate levels of studied variables.

Statistical analysis revealed that increased BMI was associated with significantly higher frequency of white bread consumption ( $p<0.05$ ), and decreased consumption of brown rice, whole grains $(p<0.01)$, wholegrain noodles, oat meal $(p<0.05)$, raw and green vegetables $(p<0.01)$, and fruits, including citruses $(p<0.01)$. The level of self-efficacy correlated positively with the consumption frequency of white rice $(p<0.05)$, noodles, raw, cooked, and green vegetables $(p<0.01)$, and fruits, including citruses $(p<0.01)$. The level of optimism was positively correlated with the frequency of brown rice, noodle, whole grain and oat meal consumption $(p<0.01)$. Finally, higher levels of satisfaction with life were associated with more frequent consumption of brown rice, noodles, whole grains, oat meal ( $p<0.01$ ), and cooked vegetables $(p<0.05)$, as well as with lower frequency of white bread consumption $(p<0.05)$. The remaining coefficients of correlation did not prove significant on statistical analysis $(p>0.05)$ (Table II).

Tab. I. Descriptive statistics of the frequency of cereal, fruit and vegetable consumption in a group of menopausal women $(n=320)$

\begin{tabular}{|c|c|c|c|c|c|c|c|}
\hline \multirow[b]{2}{*}{ Product } & \multicolumn{7}{|c|}{ Descriptive statistics } \\
\hline & 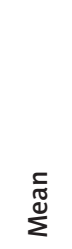 & $\begin{array}{l}\frac{\pi}{0} \\
\frac{0}{\pi} \\
\frac{\pi}{2} \\
\frac{d}{0} \\
\frac{0}{0} \\
\frac{\pi}{0} \\
\frac{\pi}{\pi} \\
\dot{0}\end{array}$ & 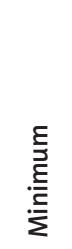 & 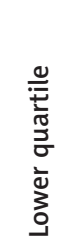 & $\frac{\frac{c}{0}}{\frac{0}{0}}$ & 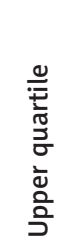 & 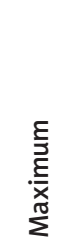 \\
\hline white bread & 5.05 & 1.86 & 1.00 & 4.00 & 5.00 & 7.00 & 7.00 \\
\hline wholegrain bread & 4.53 & 1.97 & 1.00 & 3.00 & 5.00 & 6.00 & 7.00 \\
\hline white rice & 3.24 & 1.08 & 1.00 & 3.00 & 3.00 & 4.00 & 7.00 \\
\hline brown rice & 2.13 & 1.29 & 1.00 & 1.00 & 2.00 & 3.00 & 7.00 \\
\hline non-wholegrain noodles & 3.43 & 0.70 & 2.00 & 3.00 & 3.00 & 4.00 & 5.00 \\
\hline wholegrain noodles & 2.24 & 1.00 & 1.00 & 2.00 & 2.00 & 3.00 & 5.00 \\
\hline whole grains & 2.55 & 1.13 & 1.00 & 2.00 & 3.00 & 3.00 & 5.00 \\
\hline oat meal & 2.45 & 1.79 & 1.00 & 1.00 & 1.00 & 4.00 & 7.00 \\
\hline raw vegetables & 4.99 & 1.39 & 1.00 & 4.00 & 5.00 & 6.00 & 7.00 \\
\hline cooked vegetables & 5.04 & 0.98 & 3.00 & 5.00 & 5.00 & 6.00 & 7.00 \\
\hline green vegetables & 4.88 & 1.24 & 1.00 & 4.00 & 5.00 & 6.00 & 7.00 \\
\hline fruits & 5.79 & 1.03 & 2.00 & 5.00 & 6.00 & 7.00 & 7.00 \\
\hline citrus fruits & 4.91 & 1.38 & 1.00 & 4.00 & 5.00 & 6.00 & 7.00 \\
\hline
\end{tabular}

Frequency of consumption: 7 - several times a day, 6 - once a day, 5 - several times a week, 4-once a week, 3 - several times per month, 2 - once a month, 1-rarer/never 
Tab. II. Relationship between BMI, and values of GSES, LOT-R and SWLS scales, and the frequency of cereal, fruit and vegetable consumption in a group of menopausal women $(n=320)$

\begin{tabular}{|c|c|c|c|c|}
\hline Products & BMI & GSES & LOT-R & SWLS \\
\hline white bread & $0.1284^{*}$ & -0.0843 & -0.0924 & $-0.1129^{*}$ \\
\hline $\begin{array}{l}\text { wholegrain } \\
\text { bread }\end{array}$ & -0.0938 & 0.0826 & 0.0828 & 0.0828 \\
\hline white rice & -0.0338 & $0.1341^{*}$ & 0.0462 & 0.0540 \\
\hline brown rice & $-0.1788^{\star \star}$ & -0.0107 & $0.2272^{\star \star}$ & $0.1998^{\star *}$ \\
\hline $\begin{array}{l}\text { non-wholegra- } \\
\text { in noodles }\end{array}$ & -0.0627 & $0.1738^{\star \star}$ & $0.1453^{* *}$ & $0.1587^{\star *}$ \\
\hline $\begin{array}{l}\text { wholegrain } \\
\text { noodles }\end{array}$ & $-0.1343^{\star}$ & $0.2251^{\star *}$ & $0.3906^{* *}$ & $0.3795^{\star *}$ \\
\hline whole grains & $-0.1950^{\star *}$ & -0.0225 & $0.1949^{\star *}$ & $0.1822^{* *}$ \\
\hline oat meal & $-0.1264^{*}$ & 0.0979 & $0.1848^{\star \star}$ & $0.2122^{\star \star}$ \\
\hline raw vegetables & $-0.2253^{* *}$ & $0.2848^{\star *}$ & 0.0909 & 0.1035 \\
\hline $\begin{array}{l}\text { cooked vege- } \\
\text { tables }\end{array}$ & 0.0781 & $0.3105^{\star \star}$ & 0.0782 & $0.1157^{\star}$ \\
\hline $\begin{array}{l}\text { green vegeta- } \\
\text { bles }\end{array}$ & $-0.1935^{\star \star}$ & $0.1727^{\star \star}$ & 0.0590 & 0.0541 \\
\hline fruits & $-0.2176^{\star \star}$ & $0.1911^{\star *}$ & 0.0930 & 0.0874 \\
\hline citrus fruits & $-0.2021^{* *}$ & $0.2384^{* *}$ & 0.1080 & 0.0881 \\
\hline
\end{tabular}

The level of self-efficacy exerted significant effect on the average consumption frequency of white bread $(p<0.01)$, non-wholegrain noodles $(p<0.05)$, wholegrain noodles $(p<0.01)$, whole grains $(p<0.05)$, raw, cooked and green vegetables $(p<0.01)$, and fruits $(p<0.01)$, including citruses $(p<0.01)$. Additionally, the consumption frequencies of brown rice $(p<0.01)$, non-wholegrain noodles $(p<0.05)$, wholegrain noodles $(p<0.01)$, whole grains $(p<0.01)$, oat meal $(p<0.01)$, cooked $(p<0.01)$ and green vegetables $(p<0.05)$ differed significantly depending on the level of optimism. Finally, the average consumption of brown rice $(p<0.01)$, non-wholegrain noodles $(p<0.01)$, wholegrain noodles $(p<0.01)$, whole grains $(p<0.01)$, oat meal $(p<0.01)$, cooked $(p<0.01)$ and green vegetables $(p<0.05)$ was modulated by the level of satisfaction with life among examined women. Women with high level of self-efficacy consumed white bread significantly less often with those with moderate level of this trait $(p<0.01)$. Brown rice was preferred by women with high rather than moderate $(p<0.01)$ or low levels of optimism $(p<0.05)$ and those with high rather than moderate $(p<0.01)$ or low satisfaction with life $(p<0.05)$. Nonwholegrain noodles were chosen significantly more frequently by women characterized by high rather than low level of optimism $(p<0.05)$ and by those showing high rather than low satisfaction with life $(p<0.05)$. In turn, the wholegrain noodles were significantly more often preferred by women characterized by high rather than moderate $(p<0.01)$ or low self-efficacy $(p<0.01)$, high rather than moderate or low levels of optimism $(p<0.01)$, and high rather than moderate or low satisfaction with life $(p<0.01)$. Women with high level of optimism and satisfaction of life chose whole grains significantly more frequently than those characterized by low values of these traits ( $p<0.01$ in both cases). Oat meal was considered significantly more often by women characterized by high rather than moderate $(p<0.05)$ or low levels of optimism $(p<0.01)$, and high rather than low satisfaction with life $(p<0.01)$. Raw and cooked vegetables were significantly more often preferred by women with high rather than moderate or low self-efficacy $(p<0.01)$; additionally, cooked vegetables were considered significantly more often by the participants characterized by moderate rather than low levels of optimism and satisfaction with life $(p<0.01$ in both cases). Similar tendencies were documented with regards to the preference of green vegetables. Women with high level of self-efficacy ate fruits significantly more often than those with moderate $(p<0.05)$ or low levels of this parameter $(p<0.01)$. Also the consumption of citruses followed the similar pattern (Table III).

\section{Discussion}

Our study revealed that the consumption of wholegrain cereals, fruits and vegetables among 45- to 55-year-old women is low, and determined by BMI and other analyzed individual traits (self-efficacy, optimism, and satisfaction with life).

Consumption of wholegrain cereals, fruits and vegetables represents an important diagnostic marker of nutrition, and a number of studies confirmed that it is insufficient in many population groups, including menopausal women [12-16]. Preference of examined women to non-wholegrain cereals instead of the wholegrain ones, including bread (5.05 vs. 4.53), rice (3.24 vs. 2.13 ) and noodles (3.43 vs. 2.24), should be interpreted as a negative finding. This tendency is not consistent with dietary recommendations promoting consumption of wholegrain cereals. The wholegrain products have higher biological value due to greater contents of dietary fiber and vitamin B complex, and lower values of glycemic index than in the non-wholegrain foods. This is reflected by their role in the prevention of chronic conditions, including obesity, type 2 diabetes mellitus, cardiovascular disorders, and some neoplasms $[1,17,18]$. Also fruits and vegetables play an important role in the prevention of these conditions due to their high contents of dietary fiber, antioxidative vitamins, bioflavonoids, and some minerals, including potassium and magnesium $[1,2]$. The health benefits of fruits and vegetables are also to a large extent determined by their moderate and low values of glycemic index. According to dietary guidelines, vegetables should be consumed more often than fruits due to their 
Tab. III. Frequency of cereal, fruit and vegetable consumption stratified according to the values of GSES, LOT-R and SWLS scales in a group of menopausal women $(n=320)$

\begin{tabular}{|c|c|c|c|c|c|c|c|}
\hline \multirow{2}{*}{ Products } & \multirow{2}{*}{ Value of the scale } & \multicolumn{2}{|c|}{ GSES } & \multicolumn{2}{|c|}{ LOT-R } & \multicolumn{2}{|c|}{ SWLS } \\
\hline & & $\mathrm{Me}$ & $p$ & $\mathrm{Me}$ & $p$ & $\mathrm{Me}$ & $p$ \\
\hline & $\mathrm{H}$ & 5.00 & & 5.00 & & 5.00 & \\
\hline \multirow[t]{3}{*}{ white bread } & $M$ & 6.00 & 0.0011 & 6.00 & 0.2031 & 6.00 & 0.2060 \\
\hline & $\mathrm{L}$ & 5.00 & & 6.00 & & 6.00 & \\
\hline & $\mathrm{H}$ & 5.00 & & 5.00 & & 5.00 & \\
\hline \multirow[t]{3}{*}{ wholegrain bread } & $M$ & 5.00 & 0.9900 & 4.50 & 0.1051 & 5.00 & 0.1531 \\
\hline & $\mathrm{L}$ & 5.00 & & 5.00 & & 5.00 & \\
\hline & $\mathrm{H}$ & 3.00 & & 3.00 & & 3.00 & \\
\hline \multirow[t]{3}{*}{ white rice } & $P$ & 3.00 & 0.1745 & 3.00 & 0.0993 & 3.00 & 0.0634 \\
\hline & $\mathrm{L}$ & 3.00 & & 3.00 & & 3.00 & \\
\hline & $\mathrm{H}$ & 2.00 & & 2.00 & & 2.00 & \\
\hline \multirow[t]{3}{*}{ brown rice } & $M$ & 2.00 & 0.1785 & 1.00 & $<0.0001$ & 1.00 & 0.0001 \\
\hline & $\mathrm{L}$ & 2.00 & & 2.00 & & 2.00 & \\
\hline & $\mathrm{H}$ & 4.00 & & 4.00 & & 4.00 & \\
\hline \multirow[t]{3}{*}{ non-wholegrain noodles } & $M$ & 3.00 & 0.0112 & 3.00 & 0.0057 & 3.00 & 0.0057 \\
\hline & $\mathrm{L}$ & 3.00 & & 3.00 & & 3.00 & \\
\hline & $\mathrm{H}$ & 2.00 & & 2.00 & & 2.00 & \\
\hline \multirow[t]{3}{*}{ wholegrain noodles } & $M$ & 2.00 & $<0.0001$ & 2.00 & $<0.0001$ & 2.00 & $<0.0001$ \\
\hline & $\mathrm{L}$ & 2.00 & & 2.00 & & 2.00 & \\
\hline & $\mathrm{H}$ & 2.00 & & 3.00 & & 3.00 & \\
\hline \multirow[t]{3}{*}{ whole grains } & $M$ & 3.00 & 0.0184 & 3.00 & 0.0003 & 3.00 & 0.0003 \\
\hline & $\mathrm{L}$ & 2.00 & & 2.00 & & 2.00 & \\
\hline & $\mathrm{H}$ & 1.00 & & 3.00 & & 3.00 & \\
\hline \multirow[t]{3}{*}{ oat meal } & $M$ & 1.00 & 0.5147 & 1.00 & 0.0003 & 1.00 & 0.0004 \\
\hline & $\mathrm{L}$ & 1.00 & & 1.00 & & 1.00 & \\
\hline & $\mathrm{H}$ & 5.00 & & 5.00 & & 5.00 & \\
\hline \multirow[t]{3}{*}{ raw vegetables } & $M$ & 5.00 & $<0.0001$ & 5.00 & 0.1669 & 5.00 & 0.0759 \\
\hline & $\mathrm{L}$ & 5.00 & & 5.00 & & 5.00 & \\
\hline & $\mathrm{H}$ & 5.00 & & 5.00 & & 5.00 & \\
\hline \multirow[t]{3}{*}{ cooked vegetables } & $M$ & 5.00 & $<0.0001$ & 5.00 & 0.0004 & 5.00 & 0.0011 \\
\hline & $\mathrm{L}$ & 5.00 & & 5.00 & & 5.00 & \\
\hline & $\mathrm{H}$ & 5.00 & & 5.00 & & 5.00 & \\
\hline \multirow[t]{3}{*}{ green vegetables } & $M$ & 5.00 & 0.0024 & 5.00 & 0.0238 & 5.00 & 0.0278 \\
\hline & $L$ & 5.00 & & 5.00 & & 5.00 & \\
\hline & $\mathrm{H}$ & 6.00 & & 6.00 & & 6.00 & \\
\hline \multirow[t]{3}{*}{ fruits } & $M$ & 6.00 & 0.0008 & 6.00 & 0.5447 & 6.00 & 0.6114 \\
\hline & $L$ & 5.50 & & 6.00 & & 6.00 & \\
\hline & $\mathrm{H}$ & 5.00 & & 5.00 & & 5.00 & \\
\hline \multirow[t]{2}{*}{ citrus fruits } & $M$ & 5.00 & < $<0001$ & 5.00 & 0.6774 & 5.00 & 0.4727 \\
\hline & $\mathrm{L}$ & 4.00 & 0.0001 & 5.00 & & 5.00 & \\
\hline
\end{tabular}

$H$ - high, $M$ - moderate, or L - low level of self-efficacy (GSES) / optimism (LOT-R) / satisfaction with life (SWLS); Me - median, $p$ - significance of differences determined with the Kruskal-Wallis test

lower contents of monosaccharides, i.e. nutrients increasing the risk of hyperlipidemia. However, this recommendation was not followed by our women, either. This becomes of vital importance, taking into account that cardiovascular conditions constitute the principal cause of mortality in the Polish population. Arterial hypertension and hyperlipidemia were diagnosed in $25.0 \%$ and $17.1 \%$ of our participants, respectively. 
According to an Italian study [17], Mediterranean-like diet, rich in wholegrain cereals, fruits and vegetables, and olive oil, represents a component of coronary artery disease prevention. The cardioprotective role of wholegrain cereals, associated with normalization of the lipid profile of blood, was also confirmed in a study of Danish postmenopausal women [18]. Furthermore, the preference of cereals, fruits and vegetables among menopausal women reflects the influence of these products on body weight. Predominance of products rich in dietary fiber and characterized by low glycemic index constitutes a component in a wide strategy of preventing obesity, a condition which increases the risk of other degenerative disorders [1]. As many as 30.0\% of women participating in our study were overweight, and $6.0 \%$ of them met the criteria of obesity. Previous studies confirmed that menopausal women are biologically predisposed to excessive weight gain, due to hormonal disorders and decreased basal metabolic rate among others [19]. This is reflected by high prevalence of overweight or obese women older than 40 years of age. In this context, a decrease in BMI associated with more frequent consumption of wholegrain cereals (wholegrain rice and noodles, whole grains, and oat meal), fruits and vegetables, which was documented in our study, confirmed beneficial effect of these products with regards to the maintenance of due body weight. These findings are consistent with the results of a Danish study which revealed that wholegrain products play a role in the reduction of adipose tissue in postmenopausal women [18]. This is also important for gynecological practice as excess body weight represents one of main modifiable risk factors of breast and endometrial cancer [8]. Moreover, the predictive role of obesity as risk factor of some malignancies, including breast and endometrial cancer, was revealed to increase significantly in postmenopausal women [8]. An Italian study of the dietary determinants of breast cancer confirmed the association between the diet rich in products with high glycemic index and the risk of this malignancy, in both pre- [20] and postmenopausal women [21]. This is consistent with the results of a Finnish study, pointing to the role of dietary fiber in decreasing the risk of this malignancy [22]. Also a French study confirmed increased risk of breast cancer in postmenopausal women with excess body weight who prefer products with high glycemic index [23]. These findings were also confirmed in one meta-analysis [24]. Furthermore, the results of an American study suggest that the risk of breast cancer can be decreased due to high supplementation with folic acid [25], which is consistent with a Chinese report [26], according to which frequent consumption of fruits and vegetables constitutes a component of the dietary prevention of female breast cancer.

Moreover, our study documented a significant relationship between analyzed individual traits and dietary choices regarding consumption of cereals, fruits and vegetables. Women with higher levels of self-efficacy, optimism, and satisfaction of life were characterized by more favorable dietary choices. These relationships, pointing to the predictive role of analyzed psychological traits, can be explained by their characteristics [11] and are consistent with the results of previous studies. The more rational dietary choices of women with higher level of self-efficacy can be explained by their conviction on possible achievement of various goals, also healthrelated, through the control of their determinants [11]. The positive effect of high level of self-efficacy on dietary choices of studied women can be also interpreted in terms of the positive correlation between this parameter and the internal locus of health control, associated with the conviction on ability to self-control of one's health [11]. Noticeably, the rational model of nutrition, including proper amounts of products characterized by high nutritional density, such as wholegrain cereals, fruits and vegetables, constitutes an important determinant of health potential and prevention of non-communicable chronic disorders [1]. This becomes of vital importance in the case of menopausal women, who are exposed to various health risks [8, 9]. A New Zealand study revealed the association between a higher level of self-efficacy and more frequent consumption of fruits and vegetables in a group of middle-aged Asian women [27]. In turn, an Iranian study confirmed the positive influence of high self-efficacy on consumption of fruits and vegetables among older individuals [28]. Finally, the American studies showed an indirect effect of selfefficacy on more frequent consumption of fruits and vegetables by the students of secondary schools [29, 30] and young adults [30]. Moreover, a French study identified the relationship between the locus of health control and health status; namely, the risk of lipid disorders, arterial hypertension, and excess body weight proved lower in women characterized by the internal locus of control [31]. This was consistent with more frequent consumption of wholegrain cereals, fruits and vegetables in the examined group of 45-55-year-old women. Optimism, another psychological variable analyzed in our study, modulates an array of behaviors, among them health-related ones, and correlates positively with satisfaction with life, self-efficacy, and internal locus of control [11]. The results of our study, namely the more rational dietary choices of menopausal women who were optimistic and satisfied with life, are consistent with higher prevalence of health-promoting behaviors documented previously among physically active women with a high level of optimism [32]. Both optimism and satisfaction with life modulate self-assessed condition, being a positive marker of one's health [11]. A Polish study revealed that female physicians at menopausal age assessed their condition positively; this was promoted by health-oriented behaviors, such as recreational physical 
activity, regular consumption of meals, and good mental status [33].

Cognitive and behavioral activities promoting the level of self-efficacy and optimism, and increasing the level of satisfaction with life can be useful in the improvement of nutrition in various population groups [34], including menopausal women. Previous studies revealed that reliable education programs promote internal locus of control and self-efficacy of women [35]. Consequently, consideration of psychosocial variables can be an important aspect of rational nutrition and efficient dietary intervention, and can indirectly improve one's health potential.

\section{Conclusions}

1. Observed low frequency of wholegrain cereal, fruit and vegetable consumption could decrease nutritional value and health potential of diet in menopausal women.

2. Documented inverse correlations between BMI and consumption of some wholegrain cereals, fruits and vegetables confirmed their important role in the maintenance of due weight in menopausal women.

3. Statistically significant relationships between the frequency of cereal, fruit and vegetable consumption and analyzed individual traits, pointing to the more rational dietary choices of women with higher levels of self-efficacy, optimism, and satisfaction with life, confirmed the predictive role of psychological traits as determinants of nutrition.

\section{References}

1. Kłosiewicz-Latoszek L. Dietary guidelines in prevention of chronic diseases. Probl Hig Epidemiol 2009; 90: 447-50. [in Polish]

2. Kunachowicz H, Nadolna I, Przygoda B, Iwanow K. Food composition tables. Wydawnictwo Lekarskie PZWL, Warszawa 2005. [in Polish]

3. Wright ME, Park Y, Subar AF, et al. Intakes of fruit, vegetables and botanical groups in relation to lung cancer risk in the NIH-AARP diet and health study. Am J Epidemiol 2008; 168: 1024-34.

4. Langner E, Rzeski W. Dietary derived compounds in cancer chemoprevention. Wspolczesna Onkol 2012; 16: 394-400.

5. Vaisman N, Arber N. The role of nutrition and chemoprevention in colorectal cancer: observation to expectations. Best Pract Res Clin Gastroenterol 2002; 16: 201-17.

6. Palozza P, Simone RE, Catalano A, Mele MC. Tomato lycopene and lung cancer prevention: from experimental to human studies. Cancers 2011 3: 2333-57.

7. Śmiechowska A, Bartoszek A, Namieśnik J. Cancer chemopreventive agents: Glucosinolates and their decomposition products in white cabbage (Brassica oleracea var. capitata). Postepy Hig Med Dosw 2008; 62: 125-40. [in Polish]

8. Pischon T, Nöthlings $U$, Boeing $H$. Obesity and cancer. Proc Nutr Soc 2008; 67: 128-45.

9. Stachowiak G, Zając A, Pertyński T. Metabolic syndrome in women in the menopausal period. Przegl Menopauz 2009; 1: 6-10. [in Polish]

10. Remick AK, Polivy J, Pliner P. Internal and external moderators of the effect of variety on food intake. Psychol Bull 2009; 135: 434-51.

11. Juczyński Z. Measurement tools in health promotion and health psychology. Pracownia Testów Psychologicznych, Warszawa 2009. [in Polish]
12. Chun OK, Kim DO, Smith N, et al. Daily consumption of phenolics and total antioxidant capacity from fruit and vegetables in the American diet. J Sci Food Agric 2005; 85: 1715-24.

13. Leclercq C, Arcella D, Piccinelli R, et al. The Italian National Food Consumption Survey INRAN-SCAI 2005-06: main results in terms of food consumption. Public Health Nutr 2009; 12: 2504-32.

14. Schätzer M, Rust P, Elmadfa I. Fruit and vegetable intake in Austrian adults: intake frequency, serving sizes, reasons for and barriers to consumption, and potential for increasing consumption. Public Health Nutr 2010; 13: 480-7.

15. Ilow R, Regulska-llow B, Misiewicz D, et al. Assessment of fruit and vegetable intake among the 50-yearold population of Wroclaw. Rocz Panstw Zakl Hig 2011; 62: 301-6. [in Polish]

16. Friedrich M, Podlaszewska G. Evaluation of eating habits and nutritional behaviors of women in the perimenopausal period with the diagnosed celiac disease. Rocz Panstw Zakl Hig 2012; 63: 99-104. [in Polish]

17. Bendinelli B, Masala G, Saieva C, et al. Fruit, vegetables, and olive oil and risk of coronary heart disease in Italian women: the EPICOR Study. Am J Clin Nutr 2011; 93: 275-83.

18. Kristensen M, Toubro S, Jensen MG, et al. Whole grain compared with refined wheat decreases the percentage of body fat following a 12week, energy-restricted dietary intervention in postmenopausal women. J Nutr 2012; 142: 710-6.

19. Bąk-Sosnowska M, Skrzypulec-Plinta V. The reasons for excessive body mass in menopausal women. Przegl Menopauz 2012; 1: 31-5. [in Polish]

20. Sieri S, Pala V, Brighenti F, et al. Dietary glycemic index, glycemic load, and the risk of breast cancer in an Italian prospective cohort study. Am J Clin Nutr 2007; 86: 1160-6.

21. Silvera SA, Jain M, Howe GR, et al. Dietary carbohydrates and breast cancer risk: a prospective study of the roles of overall glycemic index and glycemic load. Int J Cancer 2005; 114: 653-8.

22. Aubertin-Leheudre M, Hämäläinen E, Adlercreutz H. Diets and hormonal levels in postmenopausal women with or without breast cancer. Nutr Cancer 2011; 63: 514-24.

23. Lajous M, Boutron-Ruault MC, Fabre A, et al. Carbohydrate intake, glycemic index, glycemic load, and risk of postmenopausal breast cancer in a prospective study of French women. Am J Clin Nutr 2008; 87: 1384-91.

24. Dong JY, Qin LQ. Dietary glycemic index, glycemic load, and risk of breast cancer: meta-analysis of prospective cohort studies. Breast Cancer Res Treat 2011; 126: 287-94.

25. Shrubsole MJ, Shu XO, Li HL, et al. Dietary B vitamin and methionine intakes and breast cancer risk among Chinese women. Am J Epidemiol 2011; 173: 1171-82.

26. Bao PP, Shu XO, Zheng Y, et al. Fruit, vegetable, and animal food intake and breast cancer risk by hormone receptor status. Nutr Cancer 2012; 64: 806-19.

27. Horwath CC, Nigg CR, Motl RW, et al. Investigating fruit and vegetable consumption using the transtheoretical model. Am J Health Promot 2010; 24: 324-33.

28. Salehi L, Eftekhar H, Mohammad K, et al. Consumption of fruit and vegetables among elderly people: a cross sectional study from Iran. Nutr J 2010; 9: 2.

29. Bruening M, Kubik MY, Kenyon D, et al. Perceived barriers mediate the association between self-efficacy and fruit and vegetable consumption among students attending alternative high schools. J Am Diet Assoc 2010; 110: 1542-6.

30. Larson NI, Neumark-Sztainer D, Story M, Burgess-Champoux T. Wholegrain intake correlates among adolescents and young adults: findings from Project EAT. J Am Diet Assoc 2010; 110: 230-7.

31. Consoli SM, Bruckert E. Health locus of control and cholesterol representations. Results of the FRACTION survey. Encephale 2004; 30: 331-41.

32. Lipowski M. Level of optimism and health behavior in athletes. Med Sci Monit 2012; 18: 39-43.

33. Gojdź K, Bąk-Sosnowska M, Kołodziej S, Skrzypulec-Plinta V. Quality of life of female physicians aged 45-55 years. Przegl Menopauz 2013; 3: 213-215. [in Polish]

34. Salehi L, Mohammad K, Montazeri A. Fruit and vegetables intake among elderly Iranians: a theory-based interventional study using the five-aday program. Nutr J 2011; 10: 123.

35. Bastani F, Hashemi S, Bastani N, Haghani H. Impact of preconception health education on health locus of control and self-efficacy in women. East Mediterr Health J 2010; 16: 396-401. 